\title{
Program Pengelolaan Kebersihan Lingkungan di Pesantren
}

\author{
Misbah Zulfa Elizabeth \\ Universitas Islam Negeri Walisongo Semarang \\ Email: zulfa_elizabeth@walisongo.ac.id
}

\begin{abstract}
Abstrct: Hygiene management is an issue that is very important for the sustainability of a healthy environment. However, people in general seem difficult to implement a clean and healthy life. The presence of plastic in conjunction with the development of manufacturing has resulted into a big problem for the environment. On the other hand, Islam strongly encourages cleanliness and environmental management. Based on the above considerations by taking the focus of activities in Islamic boarding house, and to use "dialog warga"approach with the ABCD method, this program aims to change the behavior of students to be aware of the importance of hygiene, garbage sorting and understand the principle of using the principles of reuse, reduce and recycle. After the end of the program found that the process of habituation behavior of cleanliness must be preceded by changes in the knowledge system.
\end{abstract}

Abstrak: Pengelolaan kebersihan merupakan masalah yang sangat penting bagi keberlangsungan lingkungan yang sehat. Namun demikian masyarakat pada umumnya tampak sulit dalam mengimplementasikan hidup yang bersih dan sehat. Hadirnya plastik yang bersamaan dengan berkembangnya manufakturing telah mengakibatkan plastik menjadi masalah yang besar bagi lingkungan. Di sisi lain sebenarnya Islam sangat menganjurkan kebersihan dan pengelolaan lingkungan. Berdasar pertimbangan di atas dengan mengambil fokus kegiatan di pesantren, dan menggunakan pendekatan dialog warga dengan metode ABCD program ini bertujuan untuk mengubah prilaku santri agar menyadari arti penting menjaga kebersihan, memilah sampah dan memahami prinsip menggunakan kembali, menghancurkan, dan mendaur ulang. Setelah program berakhir ditemukan bahwa proses pembiasaan prilaku kebersihan harus didahului dengan perubahan sistem pengetahuan.

Kata Kunci: lingkungan, pesantren, penguatan, perempuan. 


\section{PENDAHULUAN}

Pesantren adalah sebuah lembaga pendidikan tradisional yang para siswanya tinggal bersama dan belajar di bawah bimbingan guru yang lebih dikenal dengan sebutan kiai dan mempunyai asrama untuk tempat menginap santri. Santri tersebut berada dalam kompleks yang juga menyediakan masjid untuk beribadah, ruang untuk belajar, dan kegiatan keagamaan lainnya. Kompleks ini biasanya dikelilingi oleh tembok untuk dapat mengawasi keluar masuknya para santri sesuai dengan peraturan yang berlaku (Dhofier, 2011). Pondok Pesantren merupakan sebuah istilah yang berasal dari dua kata, yaitu "pondok" dan "pesantren". Penyatuan dua istilah tersebut membentuk satu pengertian yaitu tempat belajar para santri (Malik, 2005).

Pondok pesantren merupakan lembaga pendidikan keagamaan yang tidak dapat dilepaskan dari masyarakat di mana pondok pesantren itu tumbuh dan berkembang (A'la, 2005). Sejarah menunjukkan bahwa pada umumnya pondok pesantren berada di wilayah pedesaan dan menyatu dengan kehidupan masyarakat desa. Oleh karena setting kehidupan pondok oesantren sangat beragam, karena dibentuk oleh situasi sosial dan budaya serta lingkungan fisik yang berbeda.

Dari sisi tipenya, Zamakhsyari Dhofier (2011) menegaskan adanya dua tipe pesantren, yaitu pesantren tipe lama dan tipe baru. Penentuan tipe ini didasarkan pada tipe pengajarannya. Tipe pondok pesantren yang disebut lama atau klasik adalah pondok pesantren yang mengajarkan kitab-kitab kuning dan sistem pengajarannya dengan sorogan maupun bandongan. Sementara pondok pesantren baru adalah pondok pesantren yang mengajarkan ilmu-ilmu umum dan sistem pengajarannya menggunakan kelas (klasikal). Pondok pesantren baru ini selain mengajarkan pendidikan formal di sekolah, dalam waktu-waktu yang telah ditentukan adakalanya juga mengajarkan kitab-kitab klasik.

Meskipun adanya pemilahan sebagaimana disebutkan di atas, sebenarnya keragaman pondok pesantren sangat besar. Sebagai contoh, adanya pondok pesantren yang secara khusus lebih memfokuskan pada pengajaran ilmu "alat" tertentu, seperti nahwu-shorof (ilmu tata bahasa Arab), tafsir, takhfidh atau bidang terapan tertentu, misalnya pesantren pertanian, sebagaimana difokuskan di Pondok Pesantren Al-Hikmah Sibenda Bumiayu.

Terlepas dari keragaman tipe pondok pesantren itu, pondok pesantren umumnya menjadi rujukan dalam masyarakat di mana pondok pesantren itu berada atau bahkan menjadi penggerak dalam pengembangan dan pembangunan masyarakat. Setidaknya ada dua alasan yang menyebabkan hal itu, pertama karena pondok pesantren menjadi sumber ilmu agama yang dalam masyarakat 
dipandang sebagai hal yang penting; dan kedua karena kepemimpinan pesantren yang bersifat karismatis (A'la, 2005). Pimpinan karismatis adalah pimpinan yang dipandang memiliki kekuatan spiritual tertentu sehingga diberikan tempat yang "tinggi" di dalam masyarakat karena keunggulan-keunggulan spiritual yang dimilikinya. Pondok pesantren sebagai pusat ilmu agama telah membuat masyarakat menaruh harapan besar dan menggantungkan pendidikan bagi generasi mudanya untuk dididik dalam ilmu agama maupun ilmu lainnya yang diberikan di pesantren itu.

Pondok Pesantren As-Salamah, di mana program pengabdian ini dilaksanakan, berada di wilayah desa pantai yang sangat kental dengan kondisi lingkungan yang memprihatinkan. Sampah bertebaran di mana-mana, sungai yang mengalami pendangkalan karena sampah, sistem sanitasi yang belum terkelola secara terprogram merupakan gambaran umum di desa pantai. Sebagai sebuah lembaga yang berada di wilayah pantai, maka Pondok Pesantren Putri As-Salamah menjadi gambaran mikro dari kondisi komunitas pantai tersebut. Kondisi kebersihan dan kerapihan di dalam pondok pesantren yang kurang tampak, pemakaian plastik yang tinggi, kurang terbiasanya menggunakan peralatan yang bertahan lama, tempat sampah yang kurang memadai, serta model pembuangan sampah yang kurang ramah lingkungan merupakan gambaran umum dari lingkungan yang ada di pesantren.

Dengan pertimbangan bahwa Pondok Pesantren As-Salamah berada di lingkungan desa pantai di wilayah pantai utara (pantura) Jawa Tengah yang kondisi ekologisnya membutuhkan perhatian terkait dengan kerusakan lingkungan maka kegiatan Karya Pengabdian Dosen dilaksanakan. Alasan lainnya yang menguatkan pilihan program di pesantren ini adalah: (1) Pondok Pesantren As-Salamah merupakan pondok pesantren yang tumbuh dari komunitas setempat sehingga diharapkan memiliki kekuatan kelekatan dengan komunitas setempat, yang pada gilirannya mampu menjadi rujukan bagi masyarakat setempat; (2) Pondok Pesantren As-Salamah mengasuh santri putri dengan usia antara 10-19 tahun. Secara budaya santri putri merupakan kader putri yang diharapkan memiliki peran sosial yang besar dalam proses pembudayaan nilai-nilai baru dalam masyarakat; (3) Para santri berasal dari lingkungan desa dan kecamatan di sekitar desa di mana pondok pesantren itu berada. Dengan beberapa pertimbangan di atas maka program yang berorientasi pada arah penanaman hidup bersih dan pengelolaan sampah secara pilah diharapkan akan dapat ikut serta menyelamatkan lingkungan. Penanaman pola hidup bersih dan pengelolaan sampah yang baik akan berdampak pada kehidupan diri, dan komunitas yang lebih baik. 
Dengan banyaknya jumlah santri menyebabkan semakin banyaknya sampah plastik di lingkungan selingkaran pondok pesantren karena cara para santri membuang sampah tidak mempedulikan aspek kebersihan dan kesehatan lingkungan. Penumpukan sampah plastik itu disebabkan oleh kebiasaan orang tua santri yang mengirimkan makanan kepada anak-anaknya, yaitu santri di pondok pesantren As-Salamah itu dengan kantong-kantong plastik. Kesadaran akan kebersihan, baik kebersihan pribadi, lingkungan tempat tinggal, maupun lingkungan sekitar secara umum perlu mendapatkan sentuhan pengetahuan dan penyadaran serta contoh untuk hidup bersih dan sehat agar kondisi kotor tidak berkelanjutan dan mengancam kesehatan diri dan lingkungan.

Berdasarkan analisis situasi di atas, maka dengan mempertimbangkan permasalahan yang dikemukakan oleh mitra, permasalahan yang perlu dicari solusinya adalah:

1. Kurangnya kesadaran dan pengetahuan tentang pola hidup bersih dan sehat di kalangan santri

2. Kurangnya pengetahuan mengenai pengelolaan sampah

3. Kurangnya pengetahuan mengenai arti penting pengelolaan sampah bagi lingkungan hidup yang sehat.

Dengan kondisi di atas diharapkan setelah selesainya program ini akan dicapai kondisi-kondisi di bawah ini :

1. Kesadaran dan pengetahuan untuk hidup bersih

2. Pesantren yang bersih dan sehat

3. Pengelolaan sampah yang berperspektif lingkungan

4. Pemanfaatan bahan dengan prinsip re-use dan re-cycle

5. Pesantren menjadi percontohan "pesantren bersih dan sehat" bagi masyarakat sekitar

6. Santri mampu mendiseminasikan pengetahuannya mengenai pola hidup sehat dan pengelolaan sampah

\section{STRATEGI ATAU METODE PENGABDIAN}

Program Pengelolaan Kebersihan Lingkungan di Pesantren yang mengambil lokasi di Pondok Pesantren Putri As-Salamah Desa Betahwalang Kecamatan Bonang Kabupaten Demak" ini didasari oleh konsep bahwa sikap dan prilaku merupakan bentukan budaya. Oleh karena itu dengan gagasan bahwa budaya merupakan sistem pengetahuan (Spradley, 2001) maka perubahan prilaku dan sikap harus dimulai dari perubahan sistem pengetahuan.

Perkembangan teknologi secara spesifik telah menyebabkan tingginya penggunaan kemasan makanan yang kedap udara, dan ini melibatkan industri 
kemasan dari plastik (Gilarso,2004;Jenie, 1993). Tampilan kemasan yang menarik telah memberikan keuntungan ekonomis yang tinggi bagi industriindustri pangan dan lain sebagainya untuk menarik konsumen, sekaligus menjaga kualitas produk (Tim Penulis PS, 2008). Produk yang menarik dan ditawarkan secara massive melalui media mengakibatkan tidak adanya kendali ke mana informasi menuju, tidak melihat kota atau desa. Dengan demikian, sepanjang di suatu tempat terdapat perangkat media, informasi produk pasti sampai ke tempat itu (Featherstone, 2001).

Dengan konsep dasar bahwa budaya berawal dari sistem pengetahuan, maka program ini dirancang dengan membentuk sistem pengetahuan mengenai kebersihan serta pengelolaan sampah. Pembentukan sistem pengetahuan ini akan diawali dengan workshop dan diskusi, percontohan, dan pemanfaatan "sampah" sebagai produk yang bermanfaat. Dengan dasar bahwa masalah kebersihan dan pengelolaan sampah merupakan masalah budaya yang berawal dari sistem pengetahuan dan berdampak dalam sikap dan perilaku maka program ini dirancang dengan menggunakan tiga strategi, yaitu workshop, percontohan, dan praktek implementasi re-use dan re-cycle.

Untuk menjembatani antara permasalahan yang dihadapi mitra dengan orientasi yang akan dicapai dalam program ini maka beberapa strategi dilaksanakan. Pertama, Workshop dan diskusi. Workshop dan diskusi dilaksanakan dengan melibatkan seluruh santri serta stakeholder terkait, seperti pengasuh pesantren, serta tenaga ahli. Orientasi dari workshop dan diskusi ini adalah untuk membuka wawasan pengetahuan mengenai arti penting kebersihan dan pengelolaan sampah, serta mengetahui akibat buruk jika pola hidup bersih serta pengelolaan sampah secara baik tidak dilakukan. Pola workshop akan dilakukan dengan model sharing sehingga peserta akan dapat mengungkap dengan genuine pengetahuan lokal (local knowledge) mereka. Dengan pola ini diharapkan perubahan pengetahuan dari pengetahuan asal mereka menjadi pengetahuan yang diharapkan akan terjadi.

Kedua, Percontohan pola hidup sehat dan pengelolaan sampah. Percontohan pola hidup sehat dan pengelolaan sampah secara baik ini dilakukan dengan maksud agar para santri melihat secara langsung implementasi pengetahuan yang telah diperoleh dari workshop. Percontohan dilakukan dengan cara fasilitasi peralatan yang mendukung pola hidup sehat dan pengelolaan sampah.

Dan ketiga, Implementasi konsep re-use dan re-cycle.Dalam proses ini para santri akan didampingi untuk memanfaatkan sampah yang telah dipilah untuk dapat dimanfaatkan kembali menjadi produk yang berguna. Dalam proses ini 
akan dilibatkan ahli yang telah berpengalaman mengelola limbah menjadi produk jadi.

\section{PROGRAM PENGELOLAAN KEBERSIHAN LINGKUNGAN DI PESANTREN}

Program ini dilaksanakan dengan melibatkan pihak-pihak yang authoritative dalam bidangnya masing-masing. Sebagai contoh dalam tiga kali workshop yang dilaksanakan telah melibatkan tenaga kesehatan, pejabat tingkat desa, serta tokoh agama/masyarakat, dan keluarga pesantren. Keterlibatan beberapa pihak ini dapat membuka wawasan santri secara konprehensif. Selain itu mahasiswa juga dilibatkan dalam rangka pelatihan pendampingan masyarakat (secara khusus mahasiswa jurusan Pengembangan Masyarakat Islam). Keterlibatan mahasiswa di sini memiliki orientasi strategis dalam implementasi program karena: (1). Mahasiswa jurusan Pengambangan Masyarakat Islam membutuhkan "medan" untuk berlatih dalam mengimplementasikan teori-teori yang didapatkan di bangku kuliah; dan (2) Membuka peluang jejaring dalam pembentukan desa binaan bagi pengembangan pembelajaran dan implementasi bagi jurusan Pengembangan Masyarakat Islam, dan (3) Kondisi dampingan yang berasal dari unsur generasi muda, lebih mudah jika pelaku intervensi adalah kelompok usia yang setarap, sehingga dapat dilakukan "peer-intervention".

Dengan ketersediaan stakeholder di lokus kegiatan, dibarengi dengan kemampuan dan komitmen pelaksana yang sudah terbukti dalam beberapa program pengembangan masyarakat, serta dukungan mahasiswa yang sesuai dengan bidang keilmuannya menjadikan program ini dapat terlaksana dengan baik. Ketersediaan sumber daya dan fasilitas di pondok pesantren telah memudahkan pelaksanaan program.

\section{DIALOG WARGA SEBAGAI PENDEKATAN PROGRAM}

Dialog warga merupakan salah satu bentuk strategi pengembangan dan pemberdayaan masyarakat yang saat ini banyak dikembangkan karena pelaksanaan participatory principles dipandang cukup berhasil sehingga mengundang partisipasi yang cukup kuat dari masyarakat di mana program dilaksanakan. Dialog warga ini merupakan varian terbaru dalam program pemberdayaan masyarakat. Dipandang sebagai varian baru terkait dengan transformasi orientasi, dari community empowerment menjadi community engagement.

Konsep dialog warga berasal dari strategi pemberdayaan masyarakat Asset Based Community Development (ABCD). ABCD ini merupakan strategi 
pengembangan masyarakat yang didorong oleh masyarakat secara berkelanjutan. Selain melakukan mobilisasi suatu komunitas tertentu ABCD juga berupaya untuk mengkaitkan asset mikro dengan lingkungan makro. Daya tarik ABCD adalah pada janjinya bahwa komunitas dapat mendorong proses pembangunan sendiri dengan cara mengidentifikasi dan memobilisasi asset yang ada namun seringkali tidak diketahui, dan dengan demikian strategi ini merespon dan menciptakan kesempatan perekonomian lokal. ABCD berjalan di atas asset yang telah ditemukan di dalam komunitas dan memobilisasi individu, asosiasi, dan institusi untuk bersama-sama membangun di atas assetnya, dan bukan berkonsentrasi pada kebutuhan. Dibutuhkan waktu yang cukup panjang untuk melakukan identifikasi asset individu, perkumpulan, dan lembaga-lembaga yang ada sebelum mereka dimobilisasi untuk bekerja bersama untuk membangun di atas asset yang telah diketahui. Aset individu yang telah diketahui disesuaikan dengan orang-orang atau kelompok-kelompok yang memiliki kepentingan atau kebutuhan dalam aset tersebut. Kunci untuk memulai adalah memanfaatkan apa yang ada dalam komunitas (Beuleu, 2002; Lynam., 2006).

Kekuatan kedua dari ABCD ditemukan dalam kelompok-kelompok setempat yang seharusnya mendorong proses pengembangan masyarakat serta mencari dukungan tambahan. Perkumpulan-perkumpulan ini merupakan sarana yang dapat digunakan untuk mengidentifikasi aset dan kemudian mengkaitkannya dengan asset lain sehingga dapat melipat gandakan kekuatan dan efektifitas (ABCD Institure, 2008). Pembangunan dan pengembangan masyarakat yang dikehendaki adalah pembangunan dan pengembangan masyarakat yang didorong dari dalam masyarakat sendiri, dan bukan dari luar.

Strategi ABCD menekankan prinsip partisipasi sehingga partisipasi dan pemberdayaan aktif (serta pencegahan ketidakberdayaan) menjadi dasar pelaksanaan program. Strategi itu diarahkan pada upaya pengembangan dan pemberdayaan masyarakat dengan prinsip keberlanjutan, yaitu pembangunan ekonomi yang didorong oleh masyarakat sendiri.

Dialog warga memiliki tujuan untuk mengembangkan praktek yang baik yang dimiliki warga untuk tujuan pengembangan masyarakat dengan upaya meningkatkan kompetensi warga. Ada enam tahapan atau langkah dalam dialog warga, yaitu: 1). Persiapan; 2). Mengenai kekuatan yang ada; 3). Mendekatkan mimpi; 4). Menyusun rencana aksi; 5). Merayakan mimpi bersama; 6). Implementasi rencana aksi dan pemantauan. 


\section{TAHAPAN DIALOG WARGA DALAM PELAKSANAAN PROGRAM PENGELOLAAN KEBERSIHAN DI PESANTREN}

Pelaksanaan program pengelolaan kebersihan melalui program sampah pilah dilakukan dengan dua tahapan pelaksanaan, yaitu tahap awal dan tahap pelaksanaan program. Tahap awal meliputi tahap penjajagan, tahap penyampaian program kepada stakeholder, dan tahap pembukaan secara resmi. Hasil dari proses penjajadan menghasilkan kesimpulan mengenai betapa luasnya kaitan persoalan kebersihan dengan persoalan lingkungan secara luas. Desa Betahwalang, adalah desa yang sebagian besar penduduknya mengandalkan kehidupannya pada aktifitas di sungai dan laut untuk menangkap ikan, namun kepedulian masyarakatnya sangat rendah dalam menjaga kualitas sungainya. Sungai-sungai menjadi semakin dangkal sehingga perahu harus sandar di pangkalan yang letaknya semakin jauh dari batas desa yang sungainya masih cukup dalam. Sungai tidak hanya semakin dangkal oleh timbunan sambah, namun juga semakin sempit.

Dengan titik perhatian pada aspek kebersihan dan pencemaran lingkungan itu kemudian pelaksana program mencari kemungkinan bagaimana agar program pemberdayaan masyarakat itu dapat berlangsung dengan prinsip participatory, serta mempertimbangkan pada lingkaran komunitas mana program itu akan dilaksanakan. Secara budaya, Desa Betahwalang memiliki banyak potensi pertemuan warga yang dapat digunakan sebagai wahana pertemuan antara pembawa program dengan masyarakat. Di antara berbagai pertemuan yang ada, misalnya di kalangan ibu-ibu, pertemuan PKK yang dilaksanakan setiap Jum'at pada pukul 14.00-15.00. Acara pertemuan ini biasa dilaksanakan dengan mengadakan pembacaan Surat Yasin dan bacaan tablil. Selain itu ada pertemuan nariyahan, muslimatan, fatayatan, dan pengajian di masjid. Sementara itu bapak-bapak memiliki beberapa forum pertemuan misalnya pengajian di masjid, dan pengajian rutin di rumah-rumah. Melihat potensi wahana pertemuan ini kemudian dipertimbangkan aspek strategis dari program kebersihan dan manajemen sampah pilah ini. Dengan pertimbangan bahwa motor perubahan masyarakat pada umumnya adalah generasi muda, dan posisi perempuan secara budaya yang strategis untuk pelaksanaan perubahan, maka pada akhirnya orientasi program diarahkan ke sebuah pesantren putri yaitu Pondok Pesantren Putri As-Salamah.

Pada saat penentuan Pondok Pesantren As-Salamah, pertimbangan yang mendasari adalah: 1) Pondok Pesantren As-Salamah adalah pondok pesantren putri; 2) Usia santri adalah usia remaja sehingga diharapkan para santri akan 
menjadi motor penggerak perubahan budaya kebersihan dan kepedulian lingkungan, baik di lingkungan pondok, lingkungan keluarga, dan lingkungan pertemanan mereka di mana mereka bergaul bersama teman-temannya; 3) Pengasuh Pondok Pesantren As-Salamah mendukung sepenuhnya pelaksanaan program ini dengan cara menyerahkan sepenuhnya kepada pengelola program dalam kaitan dengan kesepakatan yang dilakukan bersama dengan para santri.

Setelah mempertimbangkan beberapa hal di atas, langkah selanjutnya adalah menyampaikan secara khusus kepada pengasuh pondok pesantren mengenai rencana program. Dalam penyampaian program tersebut, semua yang terkait dengan program disampaikan, yaitu latar belakang, metode, pelaksana, orientasi, dan output program.

Dalam penyampaian latar belakang dilaksanakannya program disampaikan kepada pengasuh mengenai buruknya kondisi lingkungan di wilayah pantai yang diakibatkan oleh banyaknya sampah plastik di berbagai lingkung kehidupan masyarakat, baik di sekitar rumah, maupun di lingkungan lain seperti di sungai dan sawah. Untuk menegaskan kekhawatiran pengelola program ditunjukkan pula foto-foto penumpukan sampah yang terjadi di berbagai tempat.

Upaya pengelola program menunjukkan beberapa tayangan mengenai sampah yang ada di mana-mana telah meneguhkan pandangan pengasuh pondok pesantren bahwa pengetahuan mengenai kebersihan dan pengelolaan sampah harus segera dilakukan, dan menurut pengasuh pondok pesantren pemilihan tempat di pondok pesantren yang diasuhnya merupakan pilihan yang tepat.

Pengasuh pondok pesantren berharap agar pondok pesantrennya dapat menjadi pilot project bagi gerakan pengembangan masyarakat untuk kegiatan kebersihan lingkungan dan pengelolaan sampah. Pengasuh pondok pesantren berharap agar program pemberdayaan masyarakat dapat meluas dilakukan di Desa Betahwalang yang merupakan desa pantai dan sangat kental dengan budaya yang kurang mempedulikan lingkungan.

Selain latar belakang dilaksanakannya program, dalam tahap pengenalan program ini juga disampaikan tentang metode yang akan diterapkan dalam proses pengabdian masyarakat itu. Pengasuh menanggapi secara positif pendekatan partisipatory yang akan diterapkan dalam pelaksanaan program. Dalam kesempatan itu pengelola program juga menyampaikan adanya keterlibatan mahasiswa dalam pelaksanaan program. Arti penting keterlibatan mahasiswa dalam pengelolaan program disampaikan oleh pengelola program secara luas untuk meneguhkan pemahaman pengasuh arti penting keterlibatan mahasiswa tersebut. 
Untuk kepentingan diperolehnya pemahaman dari pengasuh pondok pesantren mengenai orientasi dan output program yang diharapkan, dengan gambar peta ditunjukkan bahwa karena orientasi dari program ini adalah pemberdayaan, maka ditegaskan bahwa program ini berupaya menggali kemampuan dan motivasi santri sendiri. Tidak ada dukungan berupa "dana segar" dari program ini. Keseluruhan proses akan melibatkan santri hingga tidakan introduksi apa yang akan dilakukan juga digali dari santri sendiri.

Untuk menjembatani kesenjangan keputusan yang diambil dalam proses pemberdayaan, maka di setiap proses dilakukan refkeksi yang melibatkan pengasuh, sehingga pengelola program, seluruh pelaksana, santri, serta pengasuh selalu berada dalam kridor pengetahuan dan kesadaran yang relatif sama. Pemahaman yang sama ini memungkinkan terlaksananya program secara baik dan memiliki daya bertahan (sustainability) yang relatif sama.

Hal-hal yang disampaikan kepada pengelola pondok pesantren juga disampaikan kepada kepala desa sebagai pemimpin pemerintahan setempat dan bertanggung jawab terhadap proses pembangunan masyarakat desa. Kepala desa memberikan dukungan sepenuhnya atas rencana program kebersihan dengan penanaman peengelompokan sampah secara pilah yang akan dilaksanakan di Pondok Pesantren Putri As-Salamah.

Kepala desa kemudian mendiseminasikan informasi akan adanya program pengabdian dengan fokus pada bidang kebersihan dan kepedulian lingkungan kepada aparat desa yang lain. Setelah informasi terdiseminasi, pengelola program membicarakan kemungkinan waktu untuk melakukan pembukaan secara resmi. Kemudian diperoleh kesepakatan waktu untuk menyelenggarakan pembukaan program secara resmi.

Meskipun telah terencana dilaksanakannya pembukaan secara resmi, namun pengelola melakukan pendekatan dengan para santri dan mulai mengintrodusir berbagai permasalahan yang berkait dengan kebersihan dan kepedulian lingkungan. Langkah ini dipandang penting karena dengan pendekatan semacam itu diperoleh ekspresi-ekspresi khas santri terkait dengan kebersihan serta perilaku yang berkait dengan kebersihan dapat disaksikan secara langsung. Pengamatan seperti ini dilakukan oleh pengelola dengan melibatkan mahasiswa.

\section{TAHAP PELAKSANAAN KEGIATAN PENGABDIAN}

Setelah dilaksanakannya pembukaan secara resmi, pengelola membentuk forum pertemuan dengan para santri, dan didampingi oleh empat orang mahasiswa dari Jurusan Pengembangan Masyarakat Islam. Forum ini dibentuk 
untuk memulai kontak secara langsung antara pengelola program dengan penerima program. Lama waktu perjalanan sesi pengantar hingga sesi mengetahui kekuatan diri adalah tiga jam.

Tujuan dari sessi ini adalah untuk mengajak santri terlibat dalam program. Untuk itu sessi diawali dengan sapaan salam yang diucapkan dengan tegas dan berulang-ulang sehingga santri tampak responsif dan bersemangat. Setelah suasana kondusif terbangun pengelola memulai komunikasi dengan mengenalkan diri, serta mengenalkan anggota tim mahasiswa. Para santri tampak sangat bersemangat karena tim pendamping adalah mahasiswa yang dari sisi usia relatif sebaya.

Sebagai pengantar program, pengelola program mengajukan beberapa pertanyaan terkait dengan kebersihan diri, lingkungan rumah, dan lingkungan secara umum. Dalam sessi awal ini para santri masih tampak ragu-ragu dalam menjawab pertanyaan pengelola. Namun demikian, dengan didampingi oleh tim mahasiswa, dan fasilitasi suasana yang dilakukan oleh pengelola pada akhirnya para santri mulai membuka suara dan memberikan respon terhadap pertanyaanpertanyaan yang diajukan.

Dengan bantuan media LCD, kemudian dilakukan penayangan slide yang berisi poster-poster ajakan hidup bersih dan berbagai pemandangan sampah dengan berbagai konteks. Ketika ditunjukkan gambar-gambar visual penumpukan sampah di sungai, jalanan, dan lingkungan pasar serta beberapa tempat lain, para santri bereaksi seolah mereka bukan bagian dari pelaku pembuangan sampah. Sessi ini, meskipun hanya berisi penayangan ajakan dan gambaran sampah di mana-mana namun pengelola selalu mengajak santri untuk berdialog, sehingga dapat diperoleh gambaran refleksi mereka atas gambargambar sampah itu. Setelah penayangan slide selesai, pengelola meminta tanggapan terhadap beberapa santri. Ada santri yang langsung menjawab, namun ada pula yang terkesan malu dan tidak berani mengemukakan pendapatnya. Situasi seperti ini dimanfaatkan oleh pengelola untuk mendorong keberanian santri untuk mengemukakan pendapat.

Setelah beberapa santri memberikan pendapatnya kemudian pengelola meminta semua santri menuliskan pandangannya mengenai suasana penuh sampah yang ditayangkan di dalam slide, serta apa harapan mereka. Mereka diminta menempelkan pendapat dan harapannya di dinding yang telah ditunjukkan. Secara keseluruhan santri menanggapi suasana penuh sampah dengan ekspresi negatif. Mereka mencela tindakan membuang sampah sembarangan serta menghancurkan ekosistem sungai dan daratan. Ekspresi tertulis mereka atas fenomena pembuangan sampah secara sembarangan 
misalnya, dengan kata-kata "keterlaluan membuang sampah sembarangan", "lingkungan kotor tidak sehat", dan "mengerikan". Sementara harapan mereka dapat ditemukan misalnya sebagaimana tampak dalam Gambar 6 di bawah ini, yang diungkapkan dalam bentuk gambar dan ekspresi kata.

Setelah peta-peta harapan ditempelkan di dinding, pengelola meminta pendapat para santri mengenai apa yang mereka gambarkan, dan diarahkan untuk merefleksi bagaimana keinginan itu dapat dicapai. Dari sessi ini diharapkan para santri menyadari arti penting mereka dalam proses menjaga lingkungan, dan arti penting berjejaring dalam rangka mewujudkan keinginan dan cita-cita mereka memiliki lingkungan hidup yang bersih dan sehat.

Sessi berikutnya adalah "membaca kekuatan yang ada”. Sessi ini dibangun dengan tujuan penyadaran akan kekuatan diri, dan semangat untuk berinovasi dalam membangun masyarakat, khususnya dalam melaksanakan program kebersihan dan kepedulian lingkungan melalui program sampah pilah. Untuk membangun kesadaran ini, pengelola dengan tim mahasiswa mendiskusikan bentuk refleksi untuk penyadaran kekuatan diri itu. Disepakati oleh pengelola dan tim mahasiswa bahwa sessi itu diawali dengan ajakan refleksi yang dipimpin oleh salah seorang mahasiswa.

Mahasiswa memimpin sessi refleksi dengan cara meminta santri untuk menutup mata selama tiga menit dan selama memejamkan mata para santri diminta membayangkan apa yang dapat dilakukan oleh para santri untuk mencapai keinginan yang telah dituliskannya tanpa meminta bantuan dari pihak luar desa jika programnya berskala desa, dan pihak luar pondok jika programnya berskala pondok pesantren.

Sessi ini dilanjutkan dengan pengungkapan refleksi oleh pengelola, dan santri diajak untuk responsif terhadap pertanyaan-pertanyaan pengelola program. Jawaban dikelompokkan menurut jenis kekuatannya dan kemudian masing-masing kelompok mendiskusikan masing-masing pilihan kekuatannya dengan panduan para mahasiswa. Kekuatan yang mengemuka dalam ekspresi santri berupa kekuatan sebagai generasi muda, sebagai santri takhfidh, sebagai penerima program (memiliki pengetahuan) dan sebagai penduduk desa Betahwalang. Pengelola mendialogkan kekuatan yang mereka petakan itu dan mendiskusikannya secara lebih mendalam dan dilanjutkan dengan penyusunan lagu kekuatan diri.

Setelah para santri dikelompokkan, dengan didampingi mahasiswa mereka menyusun lagi kekuatan yang dibatasi oleh waktu. Setelah waktu yang ditentukan. Santri menyelesaikan lagunya, dan kemudian masing-masing kelompok mempresentasikan lagu masing-masing di hadapan pengelola program 
dan pengelola pondok pesantren. Sessi ini diakhiri dengan apresiasi dari pengelola program maupun pengelola pondok pesantren dengan penegasan pentingnya mengikuti program secara aktif agar memiliki kekuatan tekad untuk membangun pesantren dan desa bersih dan sehat tanpa sampah yang dibuang secara sembarangan.

Sessi "Mendekatkan Mimpi". Sessi ini dilaksanakan dengan pendamping dari tim mahasiswa. Dengan orientasi membaca situasi untuk mencapai mimpi mereka memiliki pondok dan desa bersih, mereka dikelompokkan ke dalam empat kelompok untuk melakukan Pesantren Tour. Pesantren tour adalah strategi pemahaman lingkungan yang dilakukan dengan mengajak santri mengamati lingkungan sekitar. Kelompok satu mengamati ruang pertemuan pesantren, kelompok dua mengamati kamar dan dapur pesantren' kelompok tiga mengamati "ndalem", dan kelompok empat mengamati lingkungan sekitar pesantren.

Masing-masing kelompok terdiri dari 13 hingga 15 santri, dan mereka membuat catatan atas pandangan mereka mengenai situasi yang mereka saksikan serta rencana aksi yang dapat mereka usulkan. Pandangan dan rencana aksi atas situasi yang mereka amati itu dipresentasikan dalam forum bersama yang dihadiri oleh pengasuh.

Model presentasi hasil pengamatan dan perencanaan para santri dibuat interaktif sehingga keterlibatan seluruh peserta dapat dirasakan. Pendamping mahasiswa juga menyiapkan quiz-quiz terkait kondisi yang ditemukan para santri untuk membuat para santri benar-benar menyadari permasalahan lingkungan di sekitar mereka dan mereka memiliki tekad untuk mengatasi masalah kebersihan itu. Santri yang telah bersedia mempresentasikan hasil temuan dan menyampaikan perencanaan diberi apresiasi dengan pemberian "tanda" berupa barang yang bermanfaat untuk para santri.

Setelah mereka melakukan presentasi, pengasuh juga memberikan tanggapan dan penguatan atas perencanaan yang mereka buat. Penguatan dapat berupa penekanan kedisiplinan untuk menjalankan tugas-tugas pondok sebagaimana telah ditetapkan, juga penguatan untuk memberikan tambahan penekanan dengan adanya temuan-temuan baru dari program yang berjalan.

Sessi “Menyusun Rencana Aksi”. Sessi ini merupakan tindak lanjut dari pesantren touring. Tujuan dari sessi ini adalah untuk penyampaian temuan-temuan yang berkait dengan kebersihan dan kepedulian lingkungan. Temuan memunculkan perencanaan berupa optimalisasi manajemen pondok disampaikan kepada pengasuh dan pengurus pondok agak ada upaya optimalisasi serta pendampingan secara berkelanjutan agar program kebersihan 
dapat terealisasi secara sustainable. Sementara itu temuan yang memunculkan perencanaan pengadaan barang, diupayakan didukung oleh program.

Sebagai contoh, ditemukan kebiasaan orang tua santri yang mengantar lauk pauk dengan menggunakan kantung plastik. Oleh karena itu pengadaan yang diusulkan adalah pengadaan container (wadah) plastik sebagai stimulan, agar orang tua santri tidak menggunakan kantung plastik untuk mengantarkan lauk pauk kepada santri. Untuk temuan dan konsekuensi pengadaannya telah dilakukan, yaitu dengan memberikan stimulan wadah plastik yang cukup untuk mengantarkan lauk pauk, dengan merek Lion Star. Pertimbangan pemilihan merek itu karena merek itu memiliki kualitas yang cukup baik untuk dipakai dalam waktu yang lama, serta tutup wadah juga cukup rapat untuk menampung kuah. Semua santri mendapatkan fasilitas sampel ini, termasuk para santri baru yang baru terlibat dalam sessi akhir program.

Diharapkan dengan pemberian stimulan itu semakin tumbuh kesadaran di kalangan santri dan orang tuanya untuk menggunakan wadah-wadah yang dapat dipakai dalam waktu lama, serta mengurangi pemakaian kantung-kantung plastik. Tentu keberlangsungan program ini harus dibarengi dengan peraturan dari pihak pesantren sendiri untuk menetapkan anjuran sejalan dengan ketetapan program. Ini akan menjadi program dampingan dalam pelaksanaan program kebersihan nantinya.

Selain temuan di atas, temuan lain yang membutuhkan fasilitasi adalah adanya sampah-sampah yang bercampur antara jenis sampah organik dan nonorganik. Manajemen sampah yang tidak dispesifikasi seperti ini akan menyulitkan dalam pelaksanan program penanganan sampah pilah. Oleh karena itu diusulkan untuk diadakan tiga tempat sampah yang diperuntukkan bagi tempat sampah organik, non organik (botol dll) dan plastik bekas. Tempat sampah diletakkan di tiga tempat, yaitu samping kanan luar ndalem, dapur ndalem, dan dapur pesantren. Dengan pertimbangan kemudahan dalam pengelolaan sampah, baik untuk dibawa ke pembuangan akhir maupun ke tempat penampungan sampah recycle tempat sampah sebegaimana yang ditampakkan di atas ditempatkan di bagian luar rumah utama. Untuk tempat sampah di dapur ndalem dan dapur pesantren tempat sampah terbuat dari kaleng cat ukuran 25 $\mathrm{kg}$.

Terkait dengan penumpukan plastik di sekitaran pondok pesantren, sebagai langkah awal (meski sangat terpaksa karena banyaknya tumpukan plastik) dilakukan pembakaran. Untuk selanjutnya akan terus didampingi untuk pelaksanaan program pengurangan pemakaian kantung plastik. Untuk 
pembuangan akhir sampah organik, program membantu pembuatan lubang galian tempat pembuangan sampah itu.

Sessi "Merayakan Mimpi” dilaksanakan sebagai salah satu tahapan dalam dialog warga yang merupakan strategi pengembangan masyarakat yang diadopsi dalam program ini. Acara ini didesain untuk menyampaikan proses yang berlangsung sehingga pada tahap berikutnya pihak-pihak yang terkait dapat ikut bersama mengembangkan masyarakat dalam bidang kebersihan dan pengelolaan lingkungan. Dalam acara merayakan mimpi ini pengelola program menyampaikan kepada stakeholder mengenai proses yang telah berlangsung, temuan dari para santri terkait dengan masalah dan kekuatan yang mereka miliki, serta perencanaan yang akan mereka lakukan dalam rangka mewujudkan mimpi mereka memiliki desa yang bersih dan asri, termasuk di dalamnya pondok yang bersih, asri dan sehat.

Apa yang mereka cita-citakan termuat dalam lagu-lagu yang diciptakan oleh para santri, dengan didampingi mahasiswa. Secara spesifik, cita-cita serta kekuatan yang mengemuka dalam lagu-lagu mereka adalah: keinginan menjadikan lingkungan hidup mereka sebagai lingkungan yang bersih dan sehat serta asri, kekuatan mereka sebagai santri, sebagai generasi muda harapan bangsa, serta rasa syukur telah mendapat mencerahan ilmu dari program yang mereka ikuti.

Partisipasi santri sangat menyeluruh dalam mempersiapkan acara merayakan mimpi tersebut. Beberapa kondisi progresif yang ditemukan dalam persiapan serta acara merayakan mimpi misalnya, untuk penyiapan acara tersebut backdrop dibuat tanpa mengeluarkan biaya karena bahan yang digunakan adalah barang recycle yang berupa karton bekas kemasan yang dibuat huruf-huruf yang dibutuhkan untuk menunjukkan acara tersebut. Background menggunakan MMT yang tidak dipakai, sehingga pembiayaan untuk backdrop hanya untuk kebutuhan pembelian perekat saja.

Dalam rangkaian acara merayakan mimpi ini kepala desa menyaksikan perubahan yang cukup bermakna di lingkungan Pondok Pesantren Putri AsSalamah. Setidaknya penampilan di sekitar pondok yang menurutnya sangat berbeda dibandingkan ketika program belum dilaksanakan. Kepala desa serta pengasuh pondok pesantren juga mengharapkan akan keberlangsungan dari program kebersihan tersebut. Bahkan kepala desa mengharapkan agar gerakan kebersihan tidak berhenti di pondok pesantren As-Salamah saja, namun diperluas hingga berbagai komunitas yang ada di desa Betahwalang.

Jika diamati, perbandingan antara acara pembukaan dengan acara merayakan mimpi maka ada beberapa perbedaan yang dalam perspektif program 
kebersihan dan kepedulian lingkungan dapat dinilai sebagai suatu kemajuan. Memang secara formal acara dilaksanakan dengan susunan acara yang formal sebagaimana acara formal lainnya. Beberapa hal yang perlu mendapatkan perhatian antara lain adalah: 1. Partisipasi dalam penyiapan acara tampak semakin tampak kuat; 2. Dalam "ngormati" tamu, seperti kepala desa dan tamu undangan lain maupun para santri, pada saat pembukaan pengelola pondok memberikan hidangan dalam bentuk kemasan doz, yang di dalamnya berisi makanan kecil dan air kemasan, dan pada saat acara merayakan mimpi, kemasan doz hanya diberikan kepada tamu undangan, dan untuk para santri hidangan diberikan dalam piring-piring sehingga tidak menggunakan doz dan plastik;

\section{IMPLEMENTASI PROGRAM DAN DISEMINASI}

Untuk memastikan keberlangsungan program dengan memastikan adanya serapan pengetahuan (kognitif) sehingga memunculkan pemahaman mengenai kebersihan dan kepedulian lingkungan, sikap (afeksi), dan perilaku (psikomotorik) mahasiswa pendamping, dengan panduan dari pengelola program hadir dan bersama dengan para santri secara frekuentif, selama tiga pekan berturut-turut. Selama tiga pekan tersebut para santri melakukan refleksi mengenai apa yang telah mereka lakukan. Refleksi tersebut menyangkut pelaksanaan perencanaan yang telah mereka buat pada tahapan sebelumnya, misalnya setelah mereka melakukan pesantren touring.

Pelaksanaan refleksi mengenai implementasi program dilakukan dengan mengajukan pertanyaan yang didasarkan atas daftar pertanyaan pantauan. Adapun forum yang dibentuk adalah round-table discussion. Dengan model diskusi melingkar seperti itu, dengan sebaran empat orang mahasiswa pendamping di antara para santri maka diskusi menjadi terkendali dan merata. (daftar pertannyaan terlampir).

Prinsip dari pemantauan implementasi program dengan model roundtable discussion adalah memastikan program kebersihan melalui program sampah pilah telah terimplementasikan, dan apabila masih ditemukan masalah maka ada forum diskusi untuk menyelesaikan persoalan yang dimaksud. Sebagai contoh, dalam daftar pernyataan yang menyangkut kebersihan diri terdapat pernyataan "Minum air kemasan selalu habis", mahasiswa pendamping mengajukan pertanyaan kepada santri, apakah masih ada yang minum air minum kemasan dan tidak habis. Ketika ditemukan masih ada santri yang mengaku tidak melakukan itu, pendamping meminta pendapat santri yang lain, dan meminta pendapat bagaimana sebaiknya serta alasan dilakukannya tindakan itu. Dengan 
cara seperti itu akan muncul penguatan konsep dan pemahaman serta refleksi yang kuat di kalangan santri.

Contoh lainnya, misalnya terkait dengan tema kebersihan pondok, terdapat pernyataan "Mampu mengajak teman atau saudara lain untuk memakai wadah untuk tempat makanan dan tidak menggunakan kantong plastik" terdapat beberapa santri yang menyatakan belum melakukan itu. Mahasiswa pendamping mengajukan pertanyaan mengenai alasan tidak dilakukannya tindakan itu. Jawaban dari masing-masing santri kemudian disimpulkan untuk mendapatkan keragaman kesulitan. Kemudian digali mengenai cara mengatasi masalah tersebut.

Pertanyaan di atas memiliki kaitan yang luas, yang berkait dengan implementasi diri serta kemampuan mengajak orang lain. Implementasi pada pihak pribadi santri adalah kemauan untuk menggunakan wadah permanen untuk makanan mereka. Pihak lain yang terkait dengan masalah pemakaian kantong plastik adalah keluarga yang secara rutin membawakan makanan untuk para santri, serta mengajak rekannya untuk melakukan hal serupa.

Pernyataan yang terkait dengan tema kepedulian terhadap lingkungan yaitu “Mampu memberitahu orang lain bahaya membuang sampah di sungai/di sembarang tempat" mendapatkan respon yang sangat hangat dari para santri karena berbagai kesulitan yang mereka hadapi. Salah satu jawaban yang menarik ketika seorang santri mengatakan sulit untuk melakukan hal itu adalah karena rumah orang tuanya berada di bantaran sungai yang mengalir di desa itu, yang disadari oleh santri bahwa wilayah itu semestinya tidak untuk wilayah hunian, namun karena keterbatasan ekonomi orang tuanya memilih untuk mendirikan rumah di wilayah bantaran sungai tersebut. Ditambahkan oleh santri tersebut bahwa kekhawatirannya semakin bertambah karena kebanyakan rumah yang didirikan di bantaran sungai memagari sungai untuk keperluan perluasan batas rumahnya. Akibatnya adalah bahwa sungai semakin menyempit.

Kesadaran sebagaimana yang ditemukan dalam ungkapan-ungkapan para santri tersebut merupakan modal dasar bagi penyadaran lebih lanjut bagi para warga desa pantai pada umumnya dalam program selanjutnya. Keprihatinan seperti itu juga dikemukakan oleh pengelola pesantren maupun kepala desa. Oleh karena itu program ini secara eksplisit diharapkan memiliki keberlangsungan dan keberlanjutan sehingga harapan para santri bahwa desa Betahwalang akan menjadi desa yang hijau, asri, bersih, sehat dan ceria akan terwujud nantinya. 


\section{KESIMPULAN}

Berdasarkan pelaksanaan program Kebersihan Lingkungan melalui Program Sampah Pilah di Pondok Pesantren As-Salamah Desa Betahwalang Kecamatan Bonang Kabupaten Demak dapat disimpulkan beberapa hal di bawah ini:

1. Kurangnya kesadaran dan pengetahuan tentang pola hidup bersih dan sehat, pengelolaan sampah, dan arti penting pengelolaan sampah bagi lingkungan hidup yang sehat di kalangan santri dikarenakan oleh sistem pengetahuan para santri mengenai hal-hal itu yang masih terbatas.

2. Sistem pengetahuan merupakan basis bagi pembentukan budaya. Oleh karena itu untuk terbentuknya budaya kebersihan dan kepedulian lingkungan dibutuhkan pembangunan sistem pengetahuan yang baru. Adapun pembangunan sistem pengetahuan yang baru dapat dilakukan dengan penyadaran melalui berbagai media, di antaranya adalah program pemberdayaan melalui strategi dialog warga.

3. Strategi dialog warga merupakan strategi yang tepat untuk mendiseminasikan nilai budaya kebersihan dan kepedulian terhadap lingkungan karena strategi ini dimulai dari pembangunan kesadaran akan arti penting kebersihan melalui pembangunan pengetahuan, refleksi mengenai sikap dan prilaku sehingga dengan proses itu sistem pengetahuan mengenai kebersihan dan kepedulian terhadap lingkungan dapat menjadi basis budaya baru bagi komunitas yang mendapatkan program.

\section{DAFTAR PUSTAKA}

Ali Aziz, Muh., 2005. Dakwah Pemberdayaan Masyarakat: Paradigma Aksi Metodologi, Yogyakarta: Pustaka Pesantren.

Beauleu, L, 2002. Maping the Assets of Your Community: A Key Component for Building Local Capacity, SRDC Series\# 227, Misisisipi State: Southern Rural Development Center.

Dhofier, Zamakhsyari, 2011, Tradisi Pesantren, Jakarta: LP3ES

Effendi, Bachtiar, 1985. "Nilai Kaum Santri” dalam M. Dawam Rahardjo (ed.), Pergulatan Dunia Pesantren Jakarta: P3M. 
Featherstone, Mike, Postmdernisme dan Budaya Konsumen, terj. Misbah Zulfa Elizabeth, Yogyakarta: Pustaka Pelajar

Gilarso, T. 2004. Pengantar Ilmu Ekonomi Makro, Yogyakarta: Kanisius

Halim, A et.al., 2005. Manajemen Pesantren, Yogyakarta: Pustaka Pesantren

Jennie, Betty Sri Laksmi dan Winiarti Pudji Rahayu, 1993. Penanganan Limbah Industri Pangan, Yogyakarta: Kanisius

Korten, David C., 1987. "Development as Human Enterprise" dalam Community Management: Asian Experience and Perspectives, Conecticut: Kumarian Press.

Lynam, S, 2006. Community Development and Public Policy, Dublin: Combat Poverty Agency

Malik, Jamaluddin, 2005. Pemberdayaan Pesantren, Yogyakarta: Pustaka Pesantren.

Qomar, Mujamil, Pesantren: Dari Transformasi Metodologi Menuju Demokratisasi Institusi,

Spradley, James, 2001. Metode Etnografi, terj. Misbah Zulfa Elizabeth, Yogyakarta: PT. Tiara Wacana

Suharto, Babun, 2011. Dari Pesantren Untuk Umat: Reiventing Eksistensi Pesantren di Era Globalisasi, Surabaya: Imtiyaz.

Prasodjo, Sudjono, 1982. Profil Pesantren, Jakarta: LP3S)

Tim Penulis PS, 2008. Penanganan dan Pengelolaan Sampah, Jakarta: Penebar Swadaya.

Wirosardjono, S, 1988. "Pesantren and the Role of Islam in Indonesia" dalam Manfred Oepen dan Wolfgang, The Impact of Pesantren in Education and Community Development in Indonesia, Jakarta: P3M. 
